\title{
Complication Rates and Postoperative Renal Function in Partial Nephrectomy- Which Factors Should be Considered?
}

\section{Parsiyel Nefrektomide Komplikasyon Oranları ve Ameliyat Sonrası Böbrek Fonksiyonu- Hangi Faktörler Dikkate Alınmalıdır?}

\author{
Huseyin Cihan Demirel ${ }^{1} \mathbb{D}$, Emre Tokuc $^{2} \mathbb{D}$, Semih Turk $^{1}$ (D, Abdullah Hizir $\operatorname{Yavuzsan}^{1} \mathbb{D}$, Sedat Cakmak $^{3}$ D, \\ Sinan Levent Kirecci ${ }^{1} \mathbb{D}$, Kaya Horasanli ${ }^{1}$ (D)

\begin{abstract}
${ }^{1}$ Department of Urology, University of Health Sciences, Sisli Hamidiye Etfal Training and Research Hospital, Istanbul, Turkey ${ }^{2}$ Department of Urology, University of Health Sciences, Haydarpasa Numune Training and Research Hospital, Istanbul, Turkey ${ }^{3}$ Department of Urology, University of Health Sciences, Istanbul Haseki Training and Research Hospital, Istanbul, Turkey
\end{abstract}

Cite as: Demirel HC, Tokuc E, Turk S, Yavuzsan AH, Cakmak S, Kirecci SL, Horasanli K. Complication rates and postoperative renal function in partial nephrectomy which factors should be considered? Grand J Urol 2021;1(3):101-8.

Submission date: 27 July $2021 \quad$ Acceptance date: 19 August $2021 \quad$ Online first: 26 August $2021 \quad$ Publication date: 20 September 2021

Corresponding Author: Huseyin Cihan Demirel / University of Health Sciences, Sisli Hamidiye Etfal Training and Research Hospital, Department of Urology, Istanbul, Turkey / drhcdemirel@gmail.com ORCID ID: 0000-0001-7378-5599

\begin{abstract}
Objective: To specify the prognostic factors predicting complication rates and postoperative renal function in patients operated with partial nephrectomy. Materials and Methods: Our health center's archive system was scanned retrospectively for the time interval between January $2006-$ January 2021 for patients operated with partial nephrectomy for renal mass. History, comorbidities and laboratory results, operational information, tumor morphologies in radiographic images and its specified scores (R.E.N.A.L. score, PADUA score, C-index), peroperative and postoperative complications and pathology results of 148 regularly followed-up patients were analyzed.

Results: Mean age of the patients was $55.04 \pm 10.91$ years, ratio of male to female was 1.27 and mean tumor size was $3.56 \mathrm{~cm}$. Mean follow-up period was $55.53 \pm 42.26$ months. Postoperative creatinine value in the 6 th month showed an increase of $0.18 \mathrm{mg} / \mathrm{dl}$ compared to preoperative value. Estimated glomerular filtration rate (eGFR) also decreased by an average of $18.3 \%$. Operation of grade 4 tumors significantly affected the postoperative renal function. PADUA score $(\mathrm{p}=0.023)$ had a significant effect on postoperative GFRs and duration of ischemia. Also, difference in pre-and postoperative GFRs and its percentage change were significantly affected by $C$-index $(p=0.035, p=0.042)$. Pathological size ( $p=0.038)$, R.E.N.A.L. score ( $p=0.001)$, PADUA score $(\mathrm{p}<0.001)$, duration of ischemia $(\mathrm{p}=0.045)$ had a positively and $\mathrm{C}$-index $(\mathrm{p}=0.001)$ had a negatively significant correlation with Modified Clavien-Dindo Complication Scoring System.

Conclusion: All nephrometry scores, duration of ischemia and tumor size were associated with the complication rates according to Clavien classification. Tumor grade, PADUA score and C-index are valuable parameters for predicting renal dysfunction after partial nephrectomy.
\end{abstract}

Keywords: nephrometry score, R.E.N.A.L. score, PADUA score, C-index, nephrectomy, renal function

Öz

Amaç: Parsiyel nefrektomi yapılan hastalarda komplikasyon oranlarını ve postoperatif böbrek fonksiyonunu öngören prognostik faktörleri belirlemek. Gereçler ve Yöntemler: Ocak 2006-Ocak 2021 tarihleri arasında renal kitle nedeniyle parsiyel nefrektomi yapılan hastaların verileri hastane arşiv sisteminden retrospektif olarak tarandı. Düzenli takip edilen 148 hastanın öyküsü, komorbiditeleri ve laboratuvar sonuçları, operasyon bilgileri, radyografik görüntülerdeki tümör morfolojileri ve belirtilen skorları (R.E.N.A.L. skor, PADUA skoru, C-indeks), peroperatif ve postoperatif komplikasyonlar ve patoloji sonuçları analiz edildi.

Bulgular: Hastaların ortalama yaşı 55,04 $\pm 10,91$ yıl, erkek/kadın oranı 1,27 ve ortalama tümör boyutu 3,56 cm idi. Ortalama takip süresi $55,53 \pm 42,26$ aydı. Ameliyat sonrası kreatinin değeri 6. ayda ameliyat öncesi değere göre $0,18 \mathrm{mg} / \mathrm{dl}$ artış gösterdi. Tahmini glomerüler filtrasyon hızı (eGFR) da ortalama $\% 18,3$ oranında azaldı. Grade 4 tümörlerin operasyonu, postoperatif böbrek fonksiyonunu önemli ölçüde etkiledi. PADUA skoru ( $\mathrm{p}=0,023$ ) postoperatif GFR'ler ve iskemi süreleri üzerinde anlamlı bir etkiye sahipti. Ayrıca ameliyat öncesi ve sonrası GFR farkları ve yüzde değişimi C-indeksinden anlamlı olarak etkilenmiştir ( $\mathrm{p}=0.035, \mathrm{p}=0.042$ ). Modifiye Clavien-Dindo Komplikasyon Skorlama Sistemi ile patolojik boyut ( $\mathrm{p}=0,038$ ), R.E.N.A.L. skor $(\mathrm{p}=0,001)$, PADUA skoru $(\mathrm{p}<0,001)$, iskemi süresi $(\mathrm{p}=0,045)$ pozitif ve $\mathrm{C}$-indeks ile $(\mathrm{p}=0,001)$ negatif anlamlı ilişkiye sahipti.

Sonuç: Clavien sınıflamasına göre komplikasyon oranları, tüm nefrometri skorları, iskemi süresi ve tümör boyutu ile ilişkilidir. Parsiyel nefrektomi sonrası böbrek fonksiyon bozukluğunu öngörmede ise, tümör derecesi, PADUA skoru ve C-indeks değerli parametrelerdir.

Anahtar kelimeler: nefrometri skoru, R.E.N.A.L skor, PADUA skoru, C-indeks, nefrektomi, böbrek fonksiyonu

ORCID ID: E. Tokuc 0000-0002-5885-9278

S. Turk 0000-0001-5446-719X
A.H. Yavuzsan 0000-0002-1561-895X

S. Cakmak
$0000-0003-1942-4279$ $\begin{array}{ll}\text { S.L. Kirecci } & 0000-0002-4734-4789 \\ \text { K. Horasanli } & 0000-0001-5263-5727\end{array}$ 


\section{Introduction}

In recent years, majority of renal masses are incidentally diagnosed with the increase of advanced imaging techniques [1]. Having similar outcomes as radical nephrectomy ( $\mathrm{RN})$, partial nephrectomy (PN) has been the gold standard for $<4 \mathrm{~cm}$ renal masses [2]. As expected, the most important outcomes of PN are reduced risk of chronic kidney disease (CKD), cardiovascular disease and increased overall survival [3]. Limited indications for PN have been extended in time with observing the perioperative and oncological results and long-term overall and disease-free survival rates both in T1a $(<4 \mathrm{~cm})$ and T1b $(4-7 \mathrm{~cm})$ tumors [4].

Renal functions may be affected at various levels in patients undergoing PN due to morphological features of the tumor and operational techniques $[5,6]$. Nephrometry scores (R.E.N.A.L. score, PADUA score and C-index) announced by various centers are frequently used as predictors of outcomes after PN. Lately, studies about this subject are drawing attention and in the current study, our aim is to evaluate and sum up the factors affecting complications and renal function loss during and after PN.

\section{Materials and Methods}

Hundred and forty-eight patients that underwent open/ laparoscopic PN between January 2006- January 2021 in our high load, experienced urology clinic of a tertiary training and research hospital were evaluated in this study, and patients with missing data were excluded. The study was approved by the Ethics Committee of University of Health Sciences, Sisli Hamidiye Etfal Training and Research Hospital (Approval number: 07.07.2020/2888). A written informed consent form has been acquired from all patients included in the study indicating that their data may be used for scientific purposes. The study was performed in accordance with ethical principles of the Declaration of Helsinki and its later amendments.

Demographics, habits, comorbidities, clinical and laboratory results, tumor morphology in radiologic images (computerized tomography or magnetic-resonance imaging), surgical information (type of operation, duration of ischemia, and amount of bleeding), tumor pathology and follow-up data were recorded. Creatinine values of patients were evaluated preoperatively and postoperatively at the 6th month. Estimated glomerular filtration rate (eGFR) values were calculated with the Cockcroft-Gault formula. Peri-/post-operative complications were evaluated via the Modified Clavien-Dindo Complication Scoring System [7].

Patients without any symptoms were noted as incidental cases. Hematuria and flank pain were the mostly encountered localized symptoms. Most common systemic symptoms were fever, weight-loss and fatigue. All patients were evaluated with contrast-enhanced abdominal computerized tomography (CT) or magnetic resonance imaging (MRI) prior to surgery. Thorax CT was used for thoracic evaluation. For pathological classification, TNM (tumor-node-metastasis) 2017 criteria were used [8]. Largest size, stage and Furhman grades of the tumor were noted postoperatively. European Association of Urology (EAU) 2020 guidelines were taken into consideration to followup the patients according to their tumor stage [2].

\section{Surgical Method}

All surgeries (both open and laparoscopic) were performed by a highly experienced urology team with specialized assistants and nurses. During open PN, subcostal/transcostal flank incision was done with the patient in lateral decubitis position. All adipose tissues excepting those around the tumor were dissected. Zero-ischemia was used for small tumors with convenient localization. Renal artery clamping with mannitol infusion and renal cooling with ice-slush was used to excise bigger tumors in unsuitable locations. Masses were wedge-resected with leaving at least $0.5 \mathrm{~cm}$ safe surgical margin. Bleeding vessels were ligated with $4 / 0$ polyglactin sutures and hemostatic agents (Surgicel and Spongostan, Ethicon ${ }^{\circledR}$ Inc., Somerville, NJ, USA) placed between $U$ sutures was used for the closure of the renal parenchymal defect. All procedures were done retroperitoneally, primary repair of peritoneum was performed if peritoneal defects were encountered.

During laparoscopic PN, three or four ports were placed transperitoneally. Tumors were resected using similar techniques as in open PN, with zero-ischemia or clamping renal artery depending on the size and localization of the tumor. Defect in the renal parenchyma was repaired with V-Loc (Covidien ${ }^{\mathrm{TM}}$, Ireland) sutures.

\section{Radiological Evaluation and Nephrometry Scoring Systems}

Patients with accessible pre-operative contrast enhanced (CT/MRI) images were included in the study. These images were evaluated by two urologists from the study team in terms of the complexity of renal anatomy and nephrometry scores (R.E.N.A.L. score, PADUA score and C-index).

R.E.N.A.L. scoring system: First defined by Kutikov and Uzzo in 2009, and five characteristic features of the tumor are evaluated.

(R) Radius: Maximum tumor diameter $(\mathrm{cm}), 1$ point is given if the tumor is $\leq 4 \mathrm{~cm}, 2$ points if between $4.1-7 \mathrm{~cm}$ and 3 points if $>7 \mathrm{~cm}$.

(E) Exophytic/endophytic localization: 1 point if the tumor is $\geq 50 \%$ exophytic, 2 points if $\leq 50 \%$ exophytic, 3 points if completely endophytic.

(N) Nearness: Proximity of the tumor to the collecting system or renal sinus (mm), 1 point if $\geq 7 \mathrm{~mm}, 2$ points if $4.1-6.9$ $\mathrm{mm}, 3$ points if $\leq 4 \mathrm{~mm}$.

(A) Anterior/posterior: No scoring is made for this. Only letters of a\&p are given to the total score.

(L) Localization: 1 point if the tumor is completely above or below the polar line, 2 points if the tumor crosses the polar line, 3 points if $50 \%$ of the tumor crosses the polar line or completely 
fills the middle of the polar line.

According to this scoring, those with a total score between 4-6 are grouped as low, those between 7-9 as medium, and those between 10-12 as high risk group [9].

PADUA scoring system: Defined by Ficarra et al. at the same year as the R.E.N.A.L. score. It takes its name from the initials of Preoperative Aspects and Dimensions Used for an Anatomical (PADUA) classification of renal tumors, adapted to the city of Padua/Italy. While all other parameters are similar to the R.E.N.A.L. score, there are two differences. One is the use of the axial polar line to evaluate polar localization. The other is to evaluate laterality and renal sinus involvement with respect to the renal edge. According to this classification, kidney tumors score between 6 and 14. Depending on their anatomical localization, and 6-7 points are considered low, 8-9 points medium, and $>10$ points high-risk group [10].

C-index: Simmons et al. defined this index in 2010, one year after other scoring systems were introduced. The aim is to determine the difficulty level of the tumor resection. It measures the tumor size and the distance from the outer margin of the tumor to the center in sagittal section. The center of the kidney is calculated by taking the exact midpoint of the section where the kidney was first and last seen (distance $\mathrm{x}$ ). With the same method, the exact midpoint of the tumor is also calculated (distance y). When these points are combined to form a right triangle, the "C-index" is calculated by dividing the length of the hypotenuse (found according to the Pythagorean theorem) by the radius (r) of the tumor. According to this formula, as the $\mathrm{C}$-index value decreases, tumor resection becomes more challenging. A cut-off value of 2.5 was determined by authors, and the surgery was considered easier at a value of $>2.5$, while it was stated that a more difficult and complex surgery was required when $\mathrm{C}$-index $<2.5$ [11].

Calculation methods of R.E.N.A.L. and PADUA scoring systems, and C-index are shown in Figure 1.

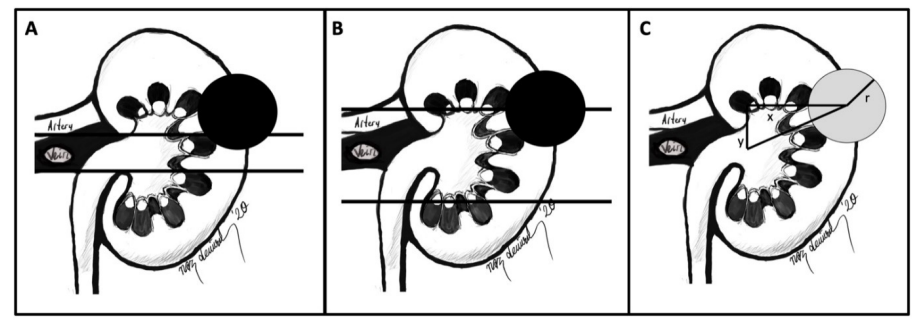

Figure 1. Calculations of nephrometry scores A) R.E.N.A.L. Score B) PADUA Score C) C-Index

\section{Statistical Method}

According to the distribution of variables, differences between two groups were analyzed using Student-T test and Mann- Whitney U test. For more than two groups, OneWay ANOVA and Kruskal- Wallis test was used. Bonferroni correction was used for evaluating multiple nonparametric subgroups. The values presented as ratios were analyzed by chi- square test. Correlations between parameters were evaluated with Spearman's rho correlation analysis. $p<0.05$ level was considered statistically significant. For all statistical analysis, SPSS 17.0 (IBM SPSS Statistics Corp., Armonk, NY, USA) software was used.

\section{Results}

Mean age of the patients was $55.04 \pm 10.91$ years. Sixty-five (43.9\%) patients were female and 83 (56.1\%) were male. Mean follow-up period was $55.53 \pm 42.26$ months. Eighty-four (56.8\%) patients had incidental renal tumors, $62(41.9 \%)$ had local, and only $2(1.3 \%)$ cases had systemic symptoms. Sixty-four (43.2\%) patients were smokers. Mean cigarette consumption rate was $12.6 \pm 23.6$ packages/year. Patients had flank pain $(\mathrm{n}=54: 36.5 \%)$, hematuria $(n=8: 5.4 \%)$, fever of unknown origin $(n=1: 0.7 \%)$, hypertension $(n=59: 39.8 \%)$, diabetes mellitus $(n=25: 16.9 \%)$, and chronic obstructive pulmonary disease $(\mathrm{n}=9: 6.1 \%)$. Mean R.E.N.A.L, PADUA scores, and C-indexes were $6.45 \pm 1.60$, $8.31 \pm 1.34$, and $2.68 \pm 1.24$, respectively.

Hundred and seventeen patients had open PN and 31 had laparoscopic PN. Mean ischemia time of all operations was $13.23 \pm 11.59$ minutes. There were no statistically significant difference between surgical methods in terms of R.E.N.A.L. scores, C-Indices, operative time, timing of surgery (mandatory/ elective), comorbidity rate or age of the patients. Duration of ischemia $(p=0.003)$ was significantly shorter in open surgery compared to laparoscopic procedures. In three cases, operation was converted from laparoscopic to open surgery. One of these patients had ureteral injury, the tumor of the second patient was suspected to be of splenic origin and in the third case surgical margin was violated.

Postoperatively, Clavien grade I-II-IIIA, IIIB, and IVA complications were observed in $55,17,3,7,1$ patients, respectively. Embolization was performed in two patients with Clavien IIIA complications, and perioperatively-placed double $\mathrm{J}$ (JJ) stent in one patient was removed. Four patients with grade IIIB complications underwent JJ stenting under general anesthesia due to discharge coming from the wound or drain site in postoperative period. One patient had persistent urinary leakage from the drain and inserted JJ stent could not solve the problem so the patient was explored. One patient was converted to open surgery because of ureteral injury during laparoscopic PN. One patient with grade IVA complications had renal loss because of postoperative renal vein thrombosis. Clavien classification was positively associated with pathological size $(\mathrm{p}=0.038)$, R.E.N.A.L. score $(\mathrm{p}=0.001)$, PADUA score $(\mathrm{p}<0.001)$, duration of ischemia $(\mathrm{p}=0.045)$ and negatively associated with $\mathrm{C}$-index $(\mathrm{p}=0.001)$ (Table 1).

Postoperative GFR changes and creatinine levels are shown in Table 2. In Grade 4 tumors, postoperative creatinine levels were significantly higher than other tumor grades (Table $\mathbf{3}$ ). Correlations between nephrometry scores and renal functions are given in Table 4. Postoperative GFRs were significantly affected 
Table 1. Comparison of complications with nephrometry scores, tumor size and ischemia times

\begin{tabular}{llllll}
\hline Clavien grade & Pathological size & R.E.N.A.L. score* & PADUA score* & Ischemia duration & C-index \\
\hline I $\quad(\mathbf{n}=\mathbf{5 5})$ & $\mathrm{p}=0.038$ & $\mathrm{p}=0.001$ & $\mathrm{p}<0.001$ & $\mathrm{p}=0.045$ \\
II $\quad(\mathbf{n}=\mathbf{1 7})$ & & & & \\
IIIA $(\mathbf{n}=\mathbf{3})$ & & & & \\
IIIB $(\mathbf{n}=7)$ & & & & \\
IVA $(\mathbf{n}=\mathbf{1})$ & & & & \\
\hline
\end{tabular}

* P values were obtained by comparing subgroups of nephrometry scores (low-moderate-high) according to complications

Table 2. Renal functions of the patients who underwent partial nephrectomy and factors affecting postoperative renal function

\begin{tabular}{|c|c|c|c|c|c|c|c|c|c|}
\hline & & & & & & \multicolumn{4}{|c|}{ Mean \pm SD /Min-Max } \\
\hline \multicolumn{6}{|c|}{ Preoperative GFR $\left(\mathrm{ml} / \mathrm{min} / 1.73 \mathrm{~m}^{2}\right)$} & \multicolumn{4}{|c|}{$90.3 \pm 27.4 / 11.1-173.0$} \\
\hline \multicolumn{6}{|c|}{ Postoperative GFR (ml/min/1.73m²) } & \multicolumn{4}{|c|}{$79.6 \pm 26.8 / 4.9-148.6$} \\
\hline \multicolumn{6}{|c|}{ GFR decrease $\left(\mathrm{ml} / \mathrm{min} / 1.73 \mathrm{~m}^{2}\right)$} & \multicolumn{4}{|c|}{$16.1 \pm 13.6 / 0-64.7$} \\
\hline \multicolumn{6}{|c|}{ GFR decrease rate $(\%)$} & \multicolumn{4}{|c|}{$18.3 \pm 16.2 / 0-109.8$} \\
\hline \multicolumn{6}{|c|}{ Preoperative creatinine (mg/dl) } & \multicolumn{4}{|c|}{$0.94 \pm 0.49 / 0.4-5.72$} \\
\hline \multicolumn{6}{|c|}{ Postoperative creatinine (mg/dl) } & \multicolumn{4}{|c|}{$1.12 \pm 0.96 / 0.49-11.6$} \\
\hline \multirow{2}{*}{\multicolumn{2}{|c|}{ Mean \pm SD }} & \multicolumn{2}{|c|}{$\begin{array}{l}\text { Postoperative GFR } \\
\qquad\left(\mathrm{ml} / \mathrm{min} / \mathbf{1 . 7 3 m ^ { 2 } )}\right.\end{array}$} & \multicolumn{2}{|c|}{$\begin{array}{l}\text { Postoperative creatinine } \\
\qquad(\mathrm{mg} / \mathrm{dl})\end{array}$} & \multicolumn{2}{|c|}{ GFR \% change } & \multicolumn{2}{|c|}{$\begin{array}{l}\text { GFR difference } \\
\left(\mathrm{ml} / \mathrm{min} / 1.73 \mathrm{~m}^{2}\right)\end{array}$} \\
\hline & & Mean \pm SD & P-values & Mean \pm SD & P-values & Mean \pm SD & P-values & $\operatorname{Mean} \pm \mathbf{S D}$ & P-values \\
\hline \multirow{4}{*}{$\begin{array}{l}\text { Tumor } \\
\text { grade }\end{array}$} & Grade 1 & $80.3 \pm 22.2$ & \multirow{4}{*}{$0.001 *$} & $0.93 \pm 0.26$ & & $18.7 \pm 11.1$ & \multirow{4}{*}{$0.012^{*}$} & $18.5 \pm 13$ & \multirow{4}{*}{0.099} \\
\hline & Grade 2 & $79.9 \pm 27.9$ & & $1.06 \pm 0.37$ & $0.001 *$ & $16.5 \pm 11.7$ & & $15.5 \pm 13$ & \\
\hline & Grade 3 & $74.1 \pm 25.0$ & & $1.15 \pm 0.46$ & & $15.7 \pm 12$ & & $13.4 \pm 13.2$ & \\
\hline & Grade 4 & $39.5 \pm 21.4$ & & $3.12 \pm 3.48$ & & $53.1 \pm 35.4$ & & $30.5 \pm 20.9$ & \\
\hline \multirow{2}{*}{ HT } & No & $82.4 \pm 25.2$ & \multirow[t]{2}{*}{0.167} & $1.15 \pm 1.23$ & 0.719 & $17.1 \pm 15.6$ & \multirow[t]{2}{*}{0.167} & $16.2 \pm 14.5$ & \multirow[t]{2}{*}{0.606} \\
\hline & Yes & $76.3 \pm 28.3$ & & $1.09 \pm 0.49$ & & $19.8 \pm 16.8$ & & $16.2 \pm 12.4$ & \\
\hline \multirow{2}{*}{ DM } & No & $80 \pm 25.5$ & \multirow[t]{2}{*}{0.738} & $1.13 \pm 1.06$ & 0.704 & $17.6 \pm 17$ & \multirow[t]{2}{*}{0.05} & $15.9 \pm 14.3$ & \multirow[t]{2}{*}{0.148} \\
\hline & Yes & $78.2 \pm 31.3$ & & $1.1 \pm 0.48$ & & $20.8 \pm 12.7$ & & $17.1 \pm 10.6$ & \\
\hline \multirow{2}{*}{$\begin{array}{l}\text { Operation } \\
\text { type }\end{array}$} & Open & $78.1 \pm 27.3$ & \multirow[t]{2}{*}{0.199} & $1.17 \pm 1.06$ & 0.066 & $19.1 \pm 17.5$ & \multirow[t]{2}{*}{0.812} & $16.6 \pm 14.5$ & \multirow[t]{2}{*}{0.886} \\
\hline & Lap & $85.5 \pm 23.5$ & & $0.92 \pm 0.29$ & & $16.1 \pm 9.7$ & & $15.2 \pm 9.8$ & \\
\hline
\end{tabular}

Table 3. Comparison of tumor grade groups according to postoperative creatinine levels

\begin{tabular}{|c|c|c|c|}
\hline & & Postoperative creatinine & GFR $\%$ change \\
\hline & & P-values & P-values \\
\hline \multirow{3}{*}{ Grade 1} & Grade 2 & $>0.99$ & $>0.99$ \\
\hline & Grade 3 & $>0.99$ & $>0.99$ \\
\hline & Grade 4 & $0.001 *$ & 0.256 \\
\hline \multirow{2}{*}{ Grade 2} & Grade 3 & $>0.99$ & $>0.99$ \\
\hline & Grade 4 & $0.002 *$ & $0.011^{*}$ \\
\hline Grade 3 & Grade 4 & $0.012 *$ & $0.010^{*}$ \\
\hline
\end{tabular}

SD: standard deviation; GFR: glomerular filtration rate; *statistically significant $p$ value $(\mathrm{p}<0.05)$ 
Table 4. Relationship between renal functions and nephrometry scores

\begin{tabular}{|c|c|c|c|c|c|c|c|c|c|c|}
\hline & \multicolumn{4}{|c|}{ R.E.N.A.L. score } & \multicolumn{3}{|c|}{ PADUA score } & \multicolumn{3}{|c|}{ C-index } \\
\hline & $4-6(n=80)$ & $7-9(n=62)$ & $\begin{array}{c}10-12 \\
(n=6) * *\end{array}$ & & 6-9 $(n=116)$ & $\begin{array}{l}10-12 \\
(n=32)\end{array}$ & & $<2.5(n=72)$ & $\geq 2.5(n=76)$ & \\
\hline & $\operatorname{Mean} \pm$ SD & Mean \pm SD & Mean \pm SD & $\mathbf{P}$ & $\operatorname{Mean} \pm$ SD & Mean \pm SD & $\mathbf{P}$ & Mean \pm SD & $\operatorname{Mean} \pm$ SD & P-values \\
\hline $\begin{array}{c}\text { Preop creatinine } \\
\text { (mg/dl) }\end{array}$ & $0.95 \pm 0.59$ & $0.94 \pm 0.34$ & $0.83 \pm 0.31$ & 0.816 & $0.94 \pm 0.53$ & $0.96 \pm 0.32$ & 0.417 & $0.91 \pm 0.27$ & $0.97 \pm 0.63$ & 0.740 \\
\hline $\begin{array}{l}\text { Postop creatinine } \\
\qquad(\mathrm{mg} / \mathrm{dl})\end{array}$ & $1.03 \pm 0.41$ & $1.25 \pm 1.4$ & $1.03 \pm 0.47$ & 0.404 & $1.02 \pm 0.39$ & $1.5 \pm 1.9$ & 0.096 & $1.23 \pm 1.31$ & $1.02 \pm 0.42$ & 0.241 \\
\hline $\begin{array}{c}\text { Preop GFR } \\
(\mathrm{mL} / \mathrm{min} / 1.73 \mathrm{~m} 2)\end{array}$ & $89.7 \pm 26.2$ & $90.1 \pm 28$ & $100.7 \pm 38.5$ & 0.941 & $91.3 \pm 26.9$ & $86.9 \pm 30.1$ & 0.149 & $89.4 \pm 25.5$ & $91.1 \pm 29.2$ & 0.710 \\
\hline $\begin{array}{c}\text { Postop GFR } \\
(\mathrm{mL} / \mathrm{min} / 1.73 \mathrm{~m} 2)\end{array}$ & $80.6 \pm 24.3$ & $78.2 \pm 29.8$ & $80.8 \pm 30$ & 0.610 & $82.0 \pm 25.3$ & $69.8 \pm 30.1$ & $0.023^{*}$ & $76.9 \pm 28.2$ & $82.1 \pm 25.3$ & 0.237 \\
\hline $\begin{array}{l}\text { GFR difference } \\
(\mathrm{ml} / \mathrm{min} / \mathbf{1 . 7 3 m} 2)\end{array}$ & $15.8 \pm 12.5$ & $15.7 \pm 14.8$ & $24.4 \pm 13.9$ & 0.562 & $15.0 \pm 11.5$ & $19.6 \pm 16.7$ & 0.225 & $18.3 \pm 14.1$ & $14.1 \pm 12.8$ & $0.035 *$ \\
\hline $\begin{array}{c}\text { GFR percentage } \\
\text { change }(\%)\end{array}$ & $18.1 \pm 15.9$ & $18.0 \pm 17.1$ & $24.0 \pm 9.2$ & 0.516 & $16.9 \pm 14.8$ & $23.1 \pm 20.1$ & 0.127 & $20.8 \pm 16.6$ & $16.0 \pm 15.5$ & $0.042 *$ \\
\hline $\begin{array}{c}\text { Duration of operation } \\
\text { (minutes) } \\
\end{array}$ & $172.1 \pm 35.8$ & $170.5 \pm 37.6$ & $165.0 \pm 37.8$ & 0.805 & $170.9 \pm 36.1$ & $171.7 \pm 38.0$ & 0.916 & $172.4 \pm 35.1$ & $169.9 \pm 37.7$ & 0.673 \\
\hline $\begin{array}{l}\text { Duration of ischemia } \\
\text { (minutes) }\end{array}$ & $11.0 \pm 12.8$ & $12.9 \pm 11.0$ & $13.8 \pm 10.1$ & 0.201 & $10.6 \pm 11.7$ & $16.1 \pm 10.6$ & $0.008^{*}$ & $11.8 \pm 10.8$ & $12.0 \pm 12.4$ & 0.822 \\
\hline
\end{tabular}

*Significant $\mathrm{p}$ value; ** It was not included in the analysis because of small number of patients; Preop: preoperative; Postop: postoperative; SD: standard deviation; GFR: glomerular filtration rate

Table 5. Relationship between ischemia times and renal functions

\begin{tabular}{|c|c|c|c|c|}
\hline & \multicolumn{3}{|c|}{ Duration of ischemia (minutes) } & \\
\hline & $0(n=60)$ & $0-20(n=55)$ & $>20(n=33)$ & \\
\hline & Mean \pm SD & Mean \pm SD & Mean \pm SD & P-values \\
\hline Postoperative creatinine (mg/dl) & $1.09 \pm 0.37$ & $1.18 \pm 1.48$ & $1.10 \pm 0.51$ & 0.206 \\
\hline Postoperative GFR $\left(\mathrm{ml} / \mathrm{min} / 1.73 \mathrm{~m}^{2}\right)$ & $77.8 \pm 23.8$ & $81.5 \pm 25.3$ & $79.7 \pm 34.1$ & 0.610 \\
\hline GFR difference $\left(\mathrm{ml} / \mathrm{min} / 1.73 \mathrm{~m}^{2}\right)$ & $15.0 \pm 13.4$ & $16.4 \pm 13.7$ & $17.8 \pm 13.9$ & 0.556 \\
\hline GFR percentage change $(\%)$ & $16.1 \pm 11.9$ & $19.8 \pm 20.2$ & $19.9 \pm 15.4$ & 0.650 \\
\hline Transfusion, n (\%) & $11(18.3)$ & $15(27.3)$ & $8(24.2)$ & 0.539 \\
\hline
\end{tabular}

SD: standard deviation; GFR: glomerular filtration rate

by PADUA scores $(\mathrm{p}=0.023)$. Additionally, PADUA scores over 10 significantly altered the duration of ischemia $(\mathrm{p}=0.008)$. Also, difference between pre-and post-operative average GFR values, and its percentage change were significantly affected by $\mathrm{C}$-index $(\mathrm{p}=0.035, \mathrm{p}=0.042)$.

Although the results of postoperative GFR, difference between pre-, and post-operative GFR values, and decrease rates in postoperative GFR were relatively more physiologic in zeroischemia group than $0-20 \mathrm{~min}-$, and $>20 \mathrm{~min}$ - ischemia groups without any statistically significant intergroup differences (Table 5).

\section{Discussion}

In recent years, management of renal masses rapidly changed from $\mathrm{RN}$ to nephron-sparing techniques to preserve kidney function and reduce associated comorbidities [3,12]. Initially, PN was only performed in mandatory indications (solitary kidney, bilateral tumors, impaired renal function etc.), but nowadays it is performed safely in patients with healthy kidneys with similar long-term oncological results as RN $[4,13]$.

$\mathrm{PN}$ instead of $\mathrm{RN}$ in $\mathrm{T} 1$ tumors has been shown to 
prevent the development of long-term renal injury in the postoperative period and consequently reduce mortality rates from cardiovascular disease [3]. Since there is a significant relationship between duration of ischemia and postoperative renal injury, ischemia times should not exceed 20-25 minutes. Thompson et al. stated each minute over 25 minutes increases the risk of acute renal injury and subsequent development of chronic renal injury by 5-6\% [14]. In a multi-institutional study by the same author concerning ischemia times during PN performed in patients with solitary kidneys, warm ischemia times over 20 minutes was associated with an increased risk of chronic renal failure and permanent requirement for dialysis [15]. Simmons et al. evaluated parenchymal atrophy measuring pre-, and post-operative parenchymal thickness, and reported development of severe parenchymal atrophy when duration of ischemia exceeded 40 minutes [16]. In a review in 2016 by Rod et al. [17] which evaluated postoperative renal functions according to duration of ischemia, zero ischemia was not superior to ischemia lasting less than 25 minutes. Gupta et al. indicated also age, comorbidity, preoperative GFR, tumor complexity, type and duration of ischemia as independent parameters affecting postoperative GFR [18]. Diversely, Çömez et al. reported no significant difference between pre-and postoperative eGFRs [19]. In our study, as the duration of ischemia increased, renal functions started to deteriorate but there were no statistically significant difference between ischemia times and postoperative GFRs, pre-, and post-operative GFRs, decreasing rates in postoperative GFRs and amount of transfused blood and/or solutions. These results we obtained in our study may be associated with very limited number of our patients had ischemia times over 25 minutes.

Nephrometry scores have been put forward to predict postoperative renal function in patients undergoing PN. $\mathrm{C}$-index is associated with glomerular filtration rate and its decrease percentage. In cases with a C-index of 2.5 or less, the risk of $30 \%$ functional loss increased 2.2-fold [20]. In our study, postoperatively GFR decreasing rates were found to be significantly different between C-index $(<2.5$ vs $\geq 2.5)$ and between PADUA score subgroups (6-9 vs 10-12). This significance was detected in difference in GFRs and GFR percentage change for $\mathrm{C}$-index and only postoperative GFR for PADUA scores. Even though there still is a higher numerical GFR difference and percentage change in PADUA 10-12 subgroup, this insignificance may caused by the asymmetrical distribution of the subgroups regarding PADUA scores (116 vs. 32). Additionally, no significant difference was detected between R.E.N.A.L. score subgroups.

Tatsugami et al. found no significant difference in postoperative renal functions between patients undergoing open/laparoscopic PN [21]. In our study, although there was a statistically significant difference between the duration of ischemia depending on the type of operation; there was no statistically significant difference between type of surgery and postoperative creatinine, pre-, and post-operative GFR values, GFR decrease and GFR decrease rates similar to the literature. Toosy et al. showed pneumoperitoneum created during laparoscopy protects the kidney from ischemia and reperfusion injury in rats [22]. Although the duration of ischemia in the laparoscopic group is increased, pneumoperitoneum created during LPN may explain the fact that ischemia time has no impact on postoperative GFR. Also, clinical studies have shown that at postoperative 6th month, renal function is not affected up to 55 minutes of ischemia times in laparoscopic cases [23]. Adamy et al. evaluated 987 patients operated by open/laparoscopic methods, stating that the average duration of ischemia was $40 \mathrm{~min}$ for open and $35 \mathrm{~min}$ for laparoscopic surgeries [24]. They also reported that the postoperative eGFR value of laparoscopically-treated patients was significantly higher compared to open surgery.

Complications such as hemorrhage, renal injury and urinary fistula may occur after PN. R.E.N.A.L., PADUA, and C-index scores may predict complications after PN. Ficarra et al. who first mentioned the concept of PADUA scoring, demonstrated that those with PADUA scores of 6-7 had 14 times lower risk of complications than those with $8-9$ and risk increased by 30 times in those with $>10$ [10]. In recent years, Draeger et al. reported that PADUA scores were more related to complication severity rather than complication rates [25]. Rosevear et al. reported that patients who developed complications after PN had higher R.E.N.A.L. scores [26]. Similarly, in our study, a statistically significantly positive correlation was found between PADUA and R.E.N.A.L. scores and severity of complications. We also found a negative association between $\mathrm{C}$-index and severity of complications.

Gill et al. reported that complications of 1800 patients undergoing open/laparoscopic PN were comparable [27]. In our study, no association was found between open/laparoscopic surgery and Clavien classification. As Patard et al. suggested, tumor size had no effect on surgical and medical complications, but they found that the blood transfusion rate was significantly higher in the group with larger tumors [28]. The reason for this discrepancy is that they had not considered blood transfusion as a complication (normally counted as Clavien II complication). We also found a statistically significant association between Clavien classification and tumor size. The main reason for this relationship is the greater amount of blood loss in large tumors. We believe excessive bleeding may be due to increased angiogenesis in large tumors.

In literature, multivariate analysis of various factors has been investigated as prognostic factors in nephron-sparing surgeries. However, to determine the values that can predict the outcomes, number of cases and regularly followed-up patients should be also considered. Even though this study has one of the longest follow-up span in the literature, low number of cases can be asserted as the main limitation of this study. This study also has the feature of being supplementary to our recent study about 
the prognostic factors indicating surgical margin status and recurrence in partial nephrectomy patients [29]. The number of patients have increased throughout the years, enriching this study. Our clinic is an experienced, high-load center but unreachable data of especially patients included earlier in the study, and the change of achiving systems are responsible for inadequate sample size. Also, our results are mostly descriptive and bivariate as the study was planned. These comparative results has the potential to be coincidental and multivariate logistic regression analysis of these findings will give more comprehensive outcomes. In recent years, performance scoring, such as Eastern Cooperative Oncology Group (ECOG), has an important role in evaluation of candidates for PN. Due to the retrospective design of the study, lack of performance scores is another limitation.

\section{Conclusions}

According to our study, R.E.N.A.L. score, PADUA score and $\mathrm{C}$-index are effective in predicting complications that may occur in patients undergoing PN. Additionally, complication rates increase in direct proportion to tumor size. According to PADUA scoring system and $\mathrm{C}$-index high-risk renal tumors cause greater renal function loss after PN compared to low risk tumors. Although the duration of ischemia did not cause a significant difference in renal function loss, tumor grade has been shown to be a direct predictor for postoperative renal functions. Nevertheless, meta-analyzes and prospective trials with higher volumes are mandatory to reach a definitive conclusion.

Ethics Committee Approval: The study was approved by the Ethics Committee of University of Health Sciences, Sisli Hamidiye Etfal Training and Research Hospital (Approval date, and Registration number: 07.07. 2020/2888).

Informed Consent: An informed consent was obtained from all patients.

Publication: The results of the study were not published elsewhere in full or in part in form of abstracts.

Peer-review: Externally peer-reviewed.

Authorship Contributions: All authors contributed to the study conception and design. Preparation of the material used and data collection: HCD, SC, AHY and SLK. Analysis of data: ST, AHY and ET. The first draft of manuscript was written by HCD and ET and edited by SLK and SC. This study was supervised by $\mathrm{KH}$ and all authors have read and approved the final manuscript. Conflict of Interest: The authors declare that they have no conflict of interest.

Financial Disclosure: The authors declare that this study received no financial support.

Acknowledgments: Thanks to Naz Demirel for illustration of nephrometry scoring systems.

\section{References}

[1] PantuckAJ,ZismanA, BelldegrunAS. The changing natural history of renal cell carcinoma. J Urol 2001;166:1611-23. https://doi.org/10.1016/s0022-5347(05)65640-6.

[2] Ljungberg B, Albiges L, Bensalah K, Bex A, Giles RH, Hora M, et al. EAU Guidelines on Renal Cell Carcinoma 2020, Arnhem, The Netherlands: European Association of Urology Guidelines Office; 2020.

https://uroweb.org/guideline/renal-cell-carcinoma/.

[3] Weight CJ, Larson BT, Fergany AF, Gao T, Lane BR, Campbell SC, et al. Nephrectomy Induced Chronic Renal Insufficiency is Associated With Increased Risk of Cardiovascular Death and Death From Any Cause in Patients With Localized cT1b Renal Masses. J Urol 2010;183:1317-23. https://doi.org/10.1016/j.juro.2009.12.030.

[4] Thompson RH, Siddiqui S, Lohse CM, Leibovich BC, Russo P, Blute ML. Partial Versus Radical Nephrectomy for 4 to $7 \mathrm{~cm}$ Renal Cortical Tumors. J Urol 2009;182:2601-6. https://doi.org/10.1016/j.juro.2009.08.087.

[5] Karamık K, İslamoğlu E, Erdemir AG, Erol İ, Yıldız A, $\mathrm{An} 1 \mathrm{l} \mathrm{H}$, et al. The associations of renal, padua and C-Index nephrometry scores with perioperative outcomes and postoperative renal function in minimally invasive partial nephrectomy. Turkish J Urol 2021;47:14-21. https://doi.org/10.5152/tud.2020.20247.

[6] Lee J, Song C, Lee D, Kim JK, You D, Jeong IG, et al. Differential contribution of the factors determining longterm renal function after partial nephrectomy over time. Urol Oncol 2021;39:196.e15-196.e20. https://doi.org/10.1016/j.urolonc.2020.11.007.

[7] Dindo D, Demartines N, Clavien PA. Classification of surgical complications: A new proposal with evaluation in a cohort of 6336 patients and results of a survey. Ann Surg 2004;240:205-13. https://doi.org/10.1097/01.sla.0000133083.54934.ae.

[8] Brierley J, Gospodarowicz MK, Wittekind C. TNM classification of malignant tumours. Eighth Ed. Chichester, West Sussex, UK: Hoboken, NJ: John Wiley \& Sons; 2017.

[9] Kutikov A, Uzzo RG. The R.E.N.A.L. Nephrometry Score: A Comprehensive Standardized System for Quantitating Renal Tumor Size, Location and Depth. J Urol 2009; 182:844-53. https://doi.org/10.1016/j.juro.2009.05.035.

[10] Ficarra V, Novara G, Secco S, Macchi V, Porzionato A, De Caro R, et al. Preoperative Aspects and Dimensions Used for an Anatomical (PADUA) Classification of Renal Tumours in Patients who are Candidates for NephronSparing Surgery. Eur Urol 2009;56:786-93. https://doi.org/10.1016/j.eururo.2009.07.040.

[11] Simmons MN, Ching CB, Samplaski MK, Park CH, Gill IS. Kidney Tumor Location Measurement Using the $\mathrm{C}$ Index Method. J Urol 2010;183:1708-13. https://doi.org/10.1016/j.juro.2010.01.005. 
[12] Ljungberg B, Cowan NC, Hanbury DC, Hora M, Kuczyk MA, Merseburger AS, et al. EAU guidelines on renal cell carcinoma: The 2010 update. Eur Urol 2010;58:398-406. https://doi.org/10.1016/j.eururo.2010.06.032.

[13] Kaouk JH, Malkoç E. Is robotic partial nephrectomy convenient for solitary kidney? Turkish J Urol 2016;42:127-9. https://doi.org/10.5152/tud.2016.69851.

[14] Thompson RH, Lane BR, Lohse CM, Leibovich BC, Fergany A, Frank I, et al. Every minute counts when the renal hilum is clamped during partial nephrectomy. Eur Urol 2010;58:340-5. https://doi.org/10.1016/j.eururo.2010.05.047.

[15] Thompson RH, Frank I, Lohse CM, Saad IR, Fergany A, Zincke H, et al. The Impact of Ischemia Time During Open Nephron Sparing Surgery on Solitary Kidneys: A Multi-Institutional Study. J Urol 2007;177:471-6. https://doi.org/10.1016/j.juro.2006.09.036.

[16] Simmons MN, Lieser GC, Fergany AF, Kaouk J, Campbell $\mathrm{SC}$. Association between warm ischemia time and renal parenchymal atrophy after partial nephrectomy. J Urol 2013;189:1638-42. https://doi.org/10.1016/j.juro.2012.11.042.

[17] Rod X, Peyronnet B, Seisen T, Pradere B, Gomez FD, Verhoest $G$, et al. Impact of ischaemia time on renal function after partial nephrectomy: a systematic review. BJU Int 2016;118:692-705. https://doi.org/10.1111/bju.13580.

[18] Gupta R, Tori M, Babitz SK, Tobert CM, Anema JG, Noyes SL, et al. Comparison of RENAL, PADUA, CSA, and PAVP nephrometry scores in predicting functional outcomes after partial nephrectomy. J Urol 2019;124:160-7. https://doi.org/10.1016/j.urology.2018.03.055.

[19] Çömez K, Çelik S, Bozkurt O, Demir Ö, Aslan G, Esen A. Partial Nephrectomy for Stage I Renal Cell Carcinoma: On-clamp or Off-clamp? J Urol Surg 2016;3:38-41. https://doi.org/10.4274/jus.2016.938.

[20] Samplaski MK, Hernandez A, Gill IS, Simmons MN. C-Index is associated with functional outcomes after laparoscopic partial nephrectomy. J Urol 2010;184:2259-63. https://doi.org/10.1016/j.juro.2010.08.031.
[21] Tatsugami K, Eto M, Yokomizo A, Kuroiwa K, Inokuchi $\mathrm{J}$, Tada $\mathrm{Y}$, et al. Impact of cold and warm ischemia on postoperative recovery of affected renal function after partial nephrectomy. J Endourol 2011;25:869-73. https://doi.org/10.1089/end.2010.0502.

[22] Toosy N, McMorris ELJ, Grace PA, Mathie RT. Ischaemic preconditioning protects the rat kidney from reperfusion injury. BJU Int 1999;84:489-94.

https://doi.org/10.1046/j.1464-410x.1999.00172.x.

[23] Bhayani SB, Rha KH, Pinto PA, Ong AM, Allaf ME, Trock BJ, et al. Laparoscopic partial nephrectomy: Effect of warm ischemia on serum creatinine. J Urol 2004;172:1264-6. https://doi.org/10.1097/01.ju.0000138187.56050.20.

[24] Adamy A, Favaretto RL, Nogueira L, Savage C, Russo P, Coleman J, et al. Recovery of renal function after open and laparoscopic partial nephrectomy. Eur Urol 2010;58:596-601. https://doi.org/10.1016/j.eururo.2010.05.044.

[25] Draeger DL, Sievert KD, Hakenberg OW. Critical evaluation of the PADUA score in a retrospective analysis of open partial nephrectomy. Turkish J Urol 2018;44:208-12. https://doi.org/10.5152/tud.2018.52721.

[26] Rosevear HM, Gellhaus PT, Lightfoot AJ, Kresowik TP, Joudi FN, Tracy CR. Utility of the RENAL nephrometry scoring system in the real world: Predicting surgeon operative preference and complication risk. BJU Int 2012;109:700-5. https://doi.org/10.1111/j.1464-410X.2011.10452.x.

[27] Gill IS, Kavoussi LR, Lane BR, Blute ML, Babineau D, Colombo JR, et al. Comparison of 1,800 Laparoscopic and Open Partial Nephrectomies for Single Renal Tumors. J Urol 2007;178:41-6. https://doi.org/10.1016/j.juro.2007.03.038.

[28] Patard JJ, Pantuck AJ, Crepel M, Lam JS, Bellec L, Albouy B, et al. Morbidity and Clinical Outcome of Nephron-Sparing Surgery in Relation to Tumour Size and Indication \{ A figure is presented . Eur Urol 2007;52:148-54. https://doi.org/10.1016/j.eururo.2007.01.039.

[29] Demirel HC, Çakmak S, Yavuzsan AH, Yeşildal C, Türk S, Dalkılınç A, et al. Prognostic factors for surgical margin status and recurrence in partial nephrectomy. Int J Clin Pract 2020;74:e13587. https://doi.org/10.1111/ijcp.13587. 